Вовк Ольга Володимирівна, магістр психології, ПрАТ «ВНЗ «МАУП», 02000, вул. Фрометівська, 2, м. Київ, Україна; <karasste@gmail.com>

ORCID: https//orcid.org/0000-0001-5274-3664

\title{
ОСОБЛИВОСТІ СИНДРОМУ ПРОФЕСІЙНОГО ВИГОРАННЯ В ПРАЦІВНИКІВ СФЕРИ ІНФОРМАЦІЙНИХ ТЕХНОЛОГІЙ
}

\begin{abstract}
Анотація
Ключові слова: професійне вигорання, сфера інформаційних технологій.

Постановка проблеми. Проблема синдрому професійного вигорання безпосередньо пов'язана 3 розробкою та впровадженням психологічних засобів для оцінки і профілактики професійного стресу, як одного з основних джерел зниження ефективності праці та порушень психічного і фізичного здоров'я професіоналів. Медико-психологічна проблема професійного вигорання осіб, які працюють у сфері інформаційних технологій, $\epsilon$ недостатньо дослідженою.

Аналіз останніх досліджень і публікацій. В контексті теоретичного вивчення проблем професійного вигорання виділяють основні етапи: виявлення та опису окремих випадків вигорання, розуміння та узагальнення феномену вигорання, дослідження вигорання та аналітичне вивчення його узагальненого концепту. Сучасний етап вивчення питання професійного вигорання характеризується появою нових напрямів досліджень, зокрема він характеризується різними сенсами, які зв'язуються з феноменом вигорання.

Формулювання мети статті. Метою $\epsilon$ теоретичне та експериментальне вивчення медико-психологічної проблеми професійного вигорання осіб, які працюють у сфері інформаційних технологій.
\end{abstract}


Виклад основного матеріалу. В працівників сфери інформаційних технологій виявлено високий $(24,4 \%)$ і середній $(35,5 \%)$ рівні імпульсивності, наявність сформованого синдрому професійного вигорання, високий рівень вразливості (46,8\%), неадекватну або нестійку самооцінку, високий рівень потреб у задоволенні, спокої, стійкій позитивній прихильності.

Висновки та перспективи подальших досліджень. В майже половини досліджуваних респондентів основної досліджуваної групи синдром професійного вигорання виявився сформованим. Серед досліджуваних респондентів переважали особи з нестійкою самооцінкою, що можна вважати фактором ризику вірогідності розвитку професійного вигорання. Отже, слід звернути увагу на вдосконалення психокорекційних втручань, які б не лише підвищували, але й стабілізували самооцінку особистості.

\section{Аннотация}

Вовк О. В., магистр психологии, ЧАО «ВУЗ «МАУП», Киев, Украина. Особенности синдрома профессионального выгорания у работников сферы информационных технологий.

Ключевые слова: профессиональное выгорание, сфера информационных технологий.

Постановка проблемы. Проблема синдрома профессионального выгорания непосредственно связана с разработкой и внедрением психологических средств для оценки и профилактики профессионального стресса как одного из основных источников снижения эффективности труда и нарушений психического и физического здоровья профессионалов. Медико-психологическая проблема профессионального выгорания лиц, работающих в сфере информационных технологий, исследована недостаточно.

Анализ последних исследований и публикаций. В контексте теоретического изучения проблем профессинального выгорания выделяют 
основные этапы: выявления и описания отдельных случаев выгорания, понимания и обобщения феномена выгорания, исследования выгорания и аналитического изучения его обобщенного концепта. Современный этап изучения вопроса профессионального выгорания характеризуется разными понятиями, связанными с данным феноменом.

Формулирование цели статьи. Целью является теоретическое и экспериментальное изучение медико-психологической проблемы профессионального вынгорания работников сферы информационных технологий.

Изложение основного материала. У работников сферы информационных технологий выявлены высокий $(24,4 \%)$ и средний $(35,5)$ уровни импульсивности, наличие сформированного синдрома профессионального выгорания, высокий уровень впечатлительности (46,8\%), неадекватная или неустойчивая самооценка, высокий уровень потребностей в удовлетворении, спокойствии, устойчивой позитивной склонности.

Выводы и перспективы дальнейших исследований. В более чем у половины исследованных респондентов основной исследуемой группы синдром профессионального выгорания оказался сформированным. Среди исследуемых респондентов преобладали лица с нестойкой самооценкой, что можно считать фактором риска вероятности развития профессионально выгорания. Таким образом, следует обратить внимание на усовершенствование психокоррекционных вмешательств, которые бы не только повышали, но и стабилизировали самооценку личности.

\section{Annotation}

Vovk OV, Magister of Psychology, The Private Joint-Stock Company Higher Educational Institution Interregional Academy of Personnel Management; Kyiv, Ukraine. Features of the syndrome of professional burnout in workers in the field of information technology.

Keywords: professional burnout, information technology. 
Formulation of the problem. The problem of the professional burnout syndrome is directly related to the development and implementation of psychological tools for evaluating and preventing occupational stress as one of the main sources of reduced work efficiency and mental and physical health problems of professionals. Medical and psychological problem of professional burnout of persons working in the field of information technology has not been adequately investigated.

Analysis of recent research and publications. In the context of the theoretical study of the problems of professional burnout, the main stages are identified: identifying and describing individual cases of burnout, understanding and summarizing the phenomenon of burnout, research on burning out and analyzing the study of its generalized concept. The modern stage of studying the issue of professional burnout is characterized by different concepts related to this phenomenon.

Formulating the purpose of the article. The goal is a theoretical and experimental study of the medical and psychological problems of professional burnout of information technology workers.

The presentation of the main material. Information technology workers have a high (24.4\%) and medium (35.5) levels of impulsivity, the presence of a developed professional burnout syndrome, a high level of impressionability $(46.8 \%)$, inadequate or unstable self-esteem, a high level of satisfaction, calm, sustained positive inclination.

Conclusions and prospects for further research. In more than half of the surveyed respondents of the main group studied, the professional burnout syndrome was formed. Persons with unstable self-esteem prevailed among the respondents, which can be considered a risk factor for the development of a professional burnout. Thus, one should pay attention to the improvement of psychocorrectional interventions, which would not only increase but also stabilize the self-esteem of the individual. 
Ключові слова: професійне вигорання,сфера інформаційних технологій.

Постановка проблеми. Проблема дослідження безпосередньо пов'язана з розробкою та впровадженням психологічних засобів для оцінки і профілактики професійного стресу, як одного 3 основних джерел зниження ефективності праці та порушень психічного i фізичного здоров'я професіоналів, а отже емоційного вигорання.

Синдром вигорання - це довготривалий, складний психофізіологічний процес, який містить в собі емоційне, психологічне, розумове і фізичне виснаження з причини тривалого емоційного навантаження.

Проблема розвитку та діагностики проблем професійного вигорання досліджувалась у роботах Г. Сельє, Б. Карвасарського, В. Мясищева, О. Свядоща, 3. Фрейда, А. Адлера, М. Хананашвілі, В. Бодрова та ін. Значна кількість досліджень присвячена вивченню особливостей різноманітних стресових станів (В. Бодров, Л. Китаєв-Смик, Н. Самоукіна, О. Полякова), зокрема дослідженню професійного стресу (М. Борневассер, Дж. Грінберг, Г. Купер, Л. Леві, Г. Леонова, Н. Водоп'янова та ін.).

Багато авторів, зокрема В. Свдокимов, В. Марищук, М. Сандомирський А. Махнач, присвятили свої роботи вивченню внутрішніх факторів, що сприяють розвитку емоційного вигорання (характеристик нервової системи, темпераменту, нейротизму, інтроверсії, тривожності, агресивності, самооцінки, локус контролю тощо). Теоретичні, методичні та практичні питання адаптації до стресу, протидії стресу, копінг-поведінки (опанувальної поведінки) знайшли відображення в роботах 3. Фрейда, А. Фрейд, Г. Сельє, Р. Лазаруса, А. Елліса,В. Абабкова, М. Перре, В. Розова та ін.

В останні десятиліття активізувалися дослідження в галузі професійної діяльності. Це обумовлено тим, що професійний простір у процесі глобалізації піддається впливу широкого спектра соціально-економічних і технологічних змін, які мають для суб’єкта праці та його професійної діяльності величезні наслідки, які потребують нового рівня адаптації. Проте 
багато питань по психології професійного стресу, залишаються відкритими. Так, недостатньо дослідженою $€$ медико-психологічна проблема професійного вигорання осіб, які працюють у сфері інформаційних технологій.

Аналіз останніх досліджень і публікацій. Ще наприкінці ХІХ ст. А. Чехов у своїх творах (зокрема, «Палата № 6» та «Іонич»), задовго до введення в науковий обіг категорії «вигорання», описав його у лікарів, точно відтворивши його динаміку та симптоматику. Окремі випадки вигорання описані в романах Т. Манна «Будденброки», «Чарівна гора» й пізніше в розповіді Г. Гріна «Випадок вигорання» [10].

У наукових доробках американських дослідників були виділені окремі випадки психічних станів із симптоматикою вигорання, i, незважаючи на те, що термін «вигорання» не використовувався, його сутність була виразно представлена. Так, Г. Бредлі описав різновид стресу, який залежить від роботи (work-related stress) [7].

Н. Гришина, застосовуючи екзистенційний рівень опису впливу емоційного вигорання на життя людини, поняття найвищих досягнень людини - акме, яке системно пов'язано із якістю життя, іiї особистісними рисами тощо. Акмеологічний контекст проблеми в такому разі обіймає цінності, сенс, смисл, мотиваційну сферу фахівця, та й не лише у професійної діяльності. Автор вважає, що розвиток емоційного вигорання не обмежується професійним середовищем та проявляється в різних життєвих ситуаціях людини, а робота, як засіб здобутку осмисленості життя, має потужний вплив на всі життєві ситуації людини [6]. Аналогічної думки дотримується також Д. Трунов, який вбачає в емоційного вигорання «позитивні» сигнали для фахівця про процеси, що відбуваються в його «душі» [3]. Дослідник визначає емоційне вигорання проявом захисних механізмів психіки, направлених на послаблення несприятливих професійних чинників - наслідків змін у мотиваційній сфері особистості фахівця. Ці результати досліджень цілком узгоджуються з поглядами В. Бойка, який розглядає емоційне вигорання у 
вигляді захисного механізму та вказує на його функціональність (дозволяє більш економно витрачати «психічну», на думку автора, енергію) та деструктивні наслідки [2].

В роботах Б. Ананьєва, з метою позначення негативного явища, яке розвивається в представників професій типу «людина-людина» i яке пов’язане 3 міжособовими відносинами, вчений використовує термін «емоційне згорання» [13]. Феномен «згорання» Б. Ананьєвим був лише зареєстрований, але не верифікований емпіричними дослідженнями.

Вперше «burnout»у 1974 р. описав Фрейденбергер, під яким розумів психологічний стан здорових людей, які перебувають в інтенсивному та тісному спілкуванні 3 пацієнтами (клієнтами) в емоційно навантаженій атмосфері при наданні професійної допомоги. «Burnout» $\epsilon$ виснаженням енергії у професіоналів у сфері соціальної допомоги, коли вони відчувають себе переобтяженими проблемами інших. Це супроводжується станом тривоги та фрустрації, що виникає в результаті відданості справі, певному життєвому стилю відносин, що призводять до провалу очікуваної винагороди. Розвиток цього «burnout» характерний у першу чергу для професій, де домінує надання допомоги людям [17].

Дослідник К. Маслач внесла нові характеристики до поняття «burnout»- це синдром фізичного та емоційного виснаження, для якого характерний розвиток негативної самооцінки, негативне ставлення до роботи, втрата розуміння та співчуття по відношенню до клієнтів або пацієнтів. У закордонній науковій літературі чітко прослідковується динамічний розвиток представленої проблематики - якщо Фрейденбергер описує умови, які необхідні для формування вигорання, такі як: інтенсивне спілкування 3 пацієнтами (клієнтами) в емоційно навантаженій атмосфері при наданні професійної допомоги, тобто при виконанні своїх професійних обов'язків, то К. Маслач вказує на зміни, які відбуваються вже безпосередньо у професіонала. 
Перші публікації щодо проблеми «вигорання» характеризувалися відсутністю емпіричних даних. Відсутність емпіричних даних не дозволяла порівняти результати різних дослідників, внаслідок чого багато критиків вказували на необхідність відмовитися від цього поняття взагалі. Відсутність систематичних досліджень вигорання пояснювалася тим, що практики виявилися зацікавленішими в цій проблемі більше, ніж академічні психологи. Стикаючись 3 вигоранням щодня, практики мали більш різносторонне уявлення про цей феномен [16].

У 80-х pp. ХХ ст. настав період конструктивного, цілеспрямованого експериментального дослідження вигорання. Різноманітні наукові ідеї доповнювалися науковими методами дослідження. Дослідникам розробка стандартизованих вимірів вигорання дала більш точні визначення та методичні інструменти. У результаті збільшилася кількість публікацій щодо феномену вигорання і його почали вивчати в багатьох країнах світу.

Безперечний інтерес представляє розуміння зарубіжними психологами синдрому «вигорання» як одновимірної конструкції. Так, дослідники А. Пайнс та I. Аронсон наголошують на тому, що «вигорання» представляє стан фізичного й психічного виснаження, який викликаний тривалим перебуванням в емоційно переобтяжених ситуаціях [15]. А. Чиром вважає «вигорання» комбінацією фізичного, емоційного та когнітивного виснаження чи стомлення.

Емоційне виснаження $є$ головним чинником «вигорання», а його додаткові компоненти - це наслідок або поведінки (купірування стресу), що призводить до деперсоналізації, або власне когнітивно-емоційного «вигорання», яке виражається в редукції особистих досягнень (деформаціях суб'єктивної оцінки власних можливостей), виявляється в деформації особистості та має безпосереднє значення для їі соціального здоров'я [4].

Вивчаючи різні точки зору щодо визначення синдрому емоційного вигорання, прослідковується тенденція трактування цього явища 3 позиції теорії стресу. 
Так, Р. Сельє нівелює вплив професійного середовища на особистість. Емоційне вигорання в цьому контексті настає в разі накопичення великої кількості негативних емоцій і відсутності способу їх розрядки. Це призводить до виснаження емоційно-енергетичних ресурсів людського організму. Таким чином, i симптоматика, яку описував Фрейденбергер, є лише проявом дистресу, тобто третьої фази загального адаптаційного синдрому, який називається «виснаженням» [20].

В. Бойко визначає емоційне вигорання як вироблений особою механізм психологічного захисту у формі повного або часткового виключення емоцій у відповідь на психотравмуючі дії [1]. В. Бойко вважає, що емоційне вигорання може носити не лише негативний характер. Саме по собі вигорання, таким чином, є конструктивним, а дисфункціональними - його наслідки, коли «вигорання» негативно позначається на виконанні професійних завдань і відносинах з колегами. Тоді ж емоційне вигорання призводить до професійної деформації особистості [21].

M. Агапова визначає сутність вигорання як перевищення психоемоційних витрат над очікуваними результатами. Чим більше виражена самоактуалізація особистості, тим реальніше та глибше емоційне вигорання [18].

Синдром емоційного вигорання дослідники Р. Абрамова, Ю. Юдчиц представляють тотожним професійній деформації [24].

Узагальнюючи результати наукових праць вітчизняних і зарубіжних психологів, Е. Зеєр відзначає, що в психологічній науці грунтовно досліджені проблеми підвищення працездатності, забезпечення надійності праці, питання професійного старіння, а також різні види професійної діяльності, пов’язані з несприятливими і екстремальними умовами праці.

Враховуючи, що вигорання є серйозною психологічною, медичною, соціальною та економічною проблемою, дослідження вигорання набуває комплексного, міждисциплінарного характеру. Наприклад, вигорання $€$ предметом клінічної психології, що вивчає ті негативні ефекти, які чинить 
вигорання на самопочуття професіоналів, на їх фізичне та психічне здоров’я. У соціальній психології вивчення вигорання здійснюються в контексті психологічних механізмів міжособових відносин між людьми. Вигорання є також предметом дослідження в організаційній психології, психології праці, психології професійного становлення особистості в контексті вивчення своєрідності професійного шляху особистості [8].

У сучасних дослідженнях наголошується, що вигорання виникає у фахівця в контексті роботи і має негативні наслідки як для нього самого, так i для організації в цілому, психічного благополуччя всіх тих, 3 ким він взаємодіє в процесі професійної діяльності (клієнтів, учнів, пацієнтів, колег). Подальше вивчення даного феномену важливе для: дослідження закономірностей і механізмів професійного становлення механізмів професійної адаптації; виявлення зв’язку між професійним стресом і соматичними розладами, та встановлення характеру цього зв’язку тощо.

Дослідниками 3 часу появи перших даних про вигорання як професійного феномену неухильно наголошується його поширеність. Якщо раніше він досліджувався у представників професій «людина - людина» вчителів, викладачів коледжів, лікарів i медичних сестер, менеджерів, торгівельних агентів, соціальних працівників, представників інших професій, пов’язаних 3 безперервними комунікаціями 3 великим потоком людей, то тепер коло професіоналів, схильних до професійного вигорання, розширилося. Дослідниками отримані дані про наявність вигорання у працівників правоохоронних органів і пенітенціарної системи, пожежників, у представників управлінських структур і у представників професії «людина знак», «людина - машина» - бухгалтерів, програмістів, пілотів, водіїв, операторів та ін. У зв’язку з цим, дослідження феномену професійного вигорання виступає одному з пріоритетних завдань сучасної науки [9].

Якісний і кількісний склад вигорання залежить від змісту професійної діяльності: у професіях «суб’єкт-суб'єктної» сфери вигорання має трикомпонентну структуру, а в «суб’єкт-об’єктній» сфері - близьку до 
двофакторної структури. Психічне вигорання набуває статусу загально професійного феномену i розглядається як компонент категоріального апарату психологічної науки. Даний феномен виявляється в різних сферах особистості - емоційній, когнітивній, мотиваційній, сфері відношення людини до роботи - і найменше розроблена проблема впливу вигорання на поза професійні сфери життя людини [14].

Аналіз сучасних досліджень показав, що «психічне вигорання» ширше поняття, ніж «професійне вигорання», оскільки воно може бути викликане різними причинами - особовими, родинними, професійними. Психічне вигорання може виявлятися не лише в професійній сфері, а, наприклад,у сім’ї, в учбовій діяльності. Професійне вигорання становить один з варіантів психічного вигорання: перше частіше використовується в контексті трудової діяльності.

Поняття «емоційне вигорання» вживається в тому разі, коли акцент робиться на емоційній складовій вигорання і йдеться про те, що вигоряє лише емоційна сфера психіки. Термін психічне вигорання використовується в разі, коли акцентується увага на тому, що вигорання зачіпає емоційну, інтелектуальну та мотиваційно-споживацьку сфери, а також вольовий механізм. На сучасному етапі вигорання вивчається одночасно як соціальний, професійний та особистісний феномени [11].

Отже, в контексті теоретичного вивчення проблем професійного вигорання виділяють основні етапи. Перший етап присвячений виявленню й опису окремих випадків вигорання. На другому етапі відбувається розуміння та узагальнення феномену вигорання. Третій період відзначається методологічною фазою дослідження вигорання. Зміст четвертого етапу полягає в аналітичному вивченні узагальненого концепту вигорання. Сучасний етап вивчення питання професійного вигорання характеризується появою нових напрямів досліджень, зокрема він характеризується різними сенсами, які зв'язуються з феноменом вигорання. 
Відповідно до концепції виникнення та розвитку стресу, розробленої Г. Сельє, робота в стресовій обстановці призводить до мобілізації внутрішніх ресурсів і може викликати як гострі порушення, так і відстрочені наслідки. Впродовж перших трьох років дії стрес-чинників зростає кількість гострих станів і реакцій (психози, інфаркти), а потім починають переважати хронічні хвороби (ішемічна хвороба серця, депресія, хвороби нирок, імунологічні захворювання та ін.). Кількість стрес-реакцій зростає за «принципом прискорення», коли вже розвинута стрес-реакція призводить до змін в житті і новим стресам, i «принципу заразливості», досить вираженому у виробничих колективах.У зв’язку з цим синдром емоційного вигорання характерний для представників сфери IT.

Відповідно до загальноприйнятих уявлень, професія програміста «інтелектуально орієнтована», тобто вимагає високого рівня розвитку інтелектуальних здібностей та таких особливостей мислення як: критичність, абстрактність, гнучкість, системність, здатність до швидкого засвоєння нового матеріалу тощо [19]. Існує набір особливостей мислення, уваги, здібностей, притаманних саме працівникам IT-сфери. Так, дослідники стверджують, що професійні програмісти мають свої риси, якості та визначають психологічні і загальнолюдські риси, здібності й особливості мислення, які повинні бути характерними для програмістів [5]. Передумовами успішної діяльності програміста визнаються такі риси: дистанційованість від інших людей, інтровертованість, заглибленість у власні інтелектуальні переживання. При називанні образних асоціацій, які викликає в них комп'ютер, на першому плані в програмістів виявляються образи, пов'язані з творінням нової реальності («особливого світу»), а робота за комп'ютером слугує свого роду замінником соціальних взаємодій [23].

Професійні програмісти, на переконання О. Волконської, мають чітко сформований образ майбутнього, вони більш самодостатні та реалістичні, ніж фахівці нижчої кваліфікації. Вільні самоописи програмістів виявилися біднішими, ніж у непрофесіоналів [22]. 
Розвиток синдрому вигорання $є$ індивідуальним та визначається відмінностями в емоційно-мотиваційній сфері, а також умовами, в яких протікає професійна діяльність людини. Клінічна картина вигорання включає ряд неспецифічних психопатологічних, психосоматичних, соматичних симптомів і ознак соціальної дисфункції. Найбільш типовими проявами є хронічна втома, когнітивна дисфункція (порушення пам'яті й уваги), порушення сну й особистісні зміни.

Синдром емоційного вигорання характерний для представників IT. До чинників, які можуть сприяти виникненню емоційного вигорання у інженерів програмістів в IT-компаніях, відносять суворий контроль над роботою програміста, часті перевірки стану проекту; надмірно стислі терміни виконання проектів і завдань; жорсткий розподіл обов’язків зверху між програмістами в команді; відсутність творчої діяльності в роботі програміста, постійне виконання програмістом рутинних операцій; відсутність можливості ведення нормального діалогу усередині команди, 3 лідером команди розробників.

Формулювання мети статті. Метою $\epsilon$ теоретичне та експериментальне вивчення медико-психологічної проблеми професійного вигорання осіб, які працюють у сфері інформаційних технологій.

Виклад основного матеріалу. Нами було проведено дослідження особливостях емоційного вигорання які працюють у сфері інформаційних технологій. У дослідженні були використані такі методики: Тестопитувальник В. Лосенкова на визначення імпульсивності та вольової саморегуляції; Методика діагностики рівня «емоційного вигорання» В. Бойка; Шкала вразливості або стресостійкості; Тест двадцяти тверджень на самоставлення (М. Кун, Т. Мак-Партланд); Колірний тест Люшера.

Відповідно до опитування за тестом В. Лосенкова на визначення імпульсивності та вольової саморегуляції, були отримані такі результати (табл. 1), де ЕГ - експериментальна група (особи, які працюють в IT-сфері), 
КГ - контрольна група (особи, які працюють в тій же компанії, але їх робота напряму не пов'язана з IT) .

Отже, бачимо, що високий рівень імпульсивності притаманний 11 $(24,4 \%)$ опитаним. Середній рівень імпульсивності притаманний 16(35,5\%)опитаним працівникам. Низький рівень імпульсивності та вольової регуляції мають 18 (40\%) опитаних.

Таблиця 1.

Результати дослідження імпульсивності особистості осіб, які працюють в

IT-сфері, за тестом В. Лосенкова

\begin{tabular}{|c|c|c|c|c|c|}
\hline \multirow{3}{*}{$\begin{array}{c}\text { Рівні } \\
\text { імпульсивності }\end{array}$} & \multicolumn{4}{|c|}{ Кількість досліджуваних } & \multirow{2}{*}{$\begin{array}{c}\text { t-критерій } \\
\text { Стьюдента } \\
\text { (число ступеней } \\
\text { свободи f=95, t- } \\
\text { критичне }=1,987 \\
\text { при рівні } \\
\text { значущості } \\
\alpha=0,05 \text { ) }\end{array}$} \\
\hline & \multicolumn{2}{|c|}{ КГ } & \multicolumn{2}{|c|}{$\mathrm{E} \Gamma$} & \\
\hline & абс. число & $\%$ & абс. число & $\%$ & \\
\hline Високий & 11 & 24,4 & 20 & 43,5 & 63,64 \\
\hline Середній & 16 & 35,5 & 18 & 38,3 & 14,14 \\
\hline Низький & 18 & 40 & 9 & 19,1 & 63,64 \\
\hline Всього & 45 & 100 & 47 & 100 & \\
\hline
\end{tabular}

Високий рівень імпульсивності притаманний 20 (43,5\%) особам, які працюють у сфері інформаційних технологій. Середній рівень імпульсивності притаманний 18 (38,3\%) опитаним. Низький рівень імпульсивності та вольової регуляції мають $9(19,1 \%)$ опитані.

Серед опитаних контрольної групи найвищий показник має низький рівень імпульсивності, середній показник має середній рівень імпульсивності та найменший показник має високий показник. Серед опитаних експериментальної групи, навпаки, найвищий показник має високий рівень імпульсивності, а найнижчий - низький рівень імпульсивності.

Результати дослідження за методикою діагностики рівня «емоційного вигорання» В. Бойка наведені в таблиці 2. (ЕГ - експериментальна група (особи, які працюють в IT-сфері), КГ - контрольна група (особи, які 
працюють в тій же компанії, але їх робота напряму не пов'язана з IT). За даними таблиці 2. бачимо, що в опитаних контрольної групи синдром не сформований у 10 (22,2\%) осіб, ознаки синдрому емоційного вигорання, який перебуває на стадії формування, притаманні 17 (37,7\%). Синдром сформовано у 18 (40\%).

Таблиця 2.

\section{Результати дослідження рівня сформованості синдрому емоційного} вигорання в працівників IT-сфери за методикою В. Бойка

\begin{tabular}{|c|c|c|c|c|c|}
\hline \multirow{3}{*}{$\begin{array}{l}\text { Рівень } \\
\text { синдрому }\end{array}$} & \multicolumn{4}{|c|}{ Кількість досліджуваних } & \multirow{3}{*}{$\begin{array}{c}\text { t-критерій } \\
\text { Стьюдента (число } \\
\text { ступеней свободи } \\
\text { f=95, t-критичне } \\
=1,987 \text { при рівні } \\
\text { значущості } \alpha=0,05 \text { ) }\end{array}$} \\
\hline & \multicolumn{2}{|c|}{ К Г } & \multicolumn{2}{|c|}{$\mathrm{E} \Gamma$} & \\
\hline & $\begin{array}{l}\text { абс. } \\
\text { Число }\end{array}$ & $\%$ & $\begin{array}{c}\text { абс. } \\
\text { число }\end{array}$ & $\%$ & \\
\hline Синдром не сформований & 10 & 22,2 & 6 & 12,7 & 28,28 \\
\hline $\begin{array}{l}\begin{array}{l}\text { Синдром на } \\
\text { формування }\end{array} \\
\end{array}$ & 17 & 37,7 & 15 & 31,9 & 14,14 \\
\hline Синдром сформований & 18 & 40 & 26 & 55,3 & 56,57 \\
\hline Всього & 45 & 100 & 47 & 100 & \\
\hline
\end{tabular}

В опитаних експериментальної групи синдром не сформований у 6 $(12,7 \%)$ осіб, ознаки синдрому емоційного вигорання, який перебуває на стадії формування, притаманні 15 (31,9\%). Синдром сформовано в 26 (55,3\%). Тобто переважна більшість респондентів мають сформований синдром професійного вигорання. У осіб, які працюють у сфері інформаційних технологій, він виражений яскравіше.

Отже, як бачимо, що і у представників інших професій компанії, і в осіб, які працюють у сфері інформаційних технологій, синдром професійного вигорання сформований у більшості респондентів і має найвищий показник. Синдром на стадії формування має середній показник прояву, не сформований синдром професійного вигорання в невеликої кількості опитаних і має найнижчий показник. 
Відповідно до дослідження за методикою «Шкала вразливості або стресостійкості», були отримані результати, представлені в таблиці 3. (ЕГ експериментальна група (особи, які працюють в IT-сфері), КГ - контрольна група (особи, які працюють в тій же компанії, але їх робота напряму не пов'язана з IT).

Таблиця 3.

\section{Результати дослідження вразливості працівників IT-сфери за методикою} «Шкала вразливості або стресостійкості»

\begin{tabular}{|c|c|c|c|c|c|}
\hline \multirow{3}{*}{$\begin{array}{l}\text { Рівні } \\
\text { вразливості }\end{array}$} & \multicolumn{4}{|c|}{ Кількість досліджуваних } & \multirow{3}{*}{$\begin{array}{c}\text { t-критерій } \\
\text { Стьюдента (число } \\
\text { ступеней свободи } \\
\text { f=95, t-критичне } \\
=1,987 \text { при рівні } \\
\text { значущості } \alpha=0,05 \text { ) }\end{array}$} \\
\hline & \multicolumn{2}{|c|}{$\mathrm{K} \Gamma$} & \multicolumn{2}{|c|}{$\mathrm{E} \Gamma$} & \\
\hline & абс. число & $\%$ & абс. число & $\%$ & \\
\hline Високий & 11 & 24,4 & 22 & 46,8 & 77,78 \\
\hline Середній & 16 & 35,5 & 16 & 34,04 & 0,00 \\
\hline Низький & 18 & 40 & 9 & 19,15 & 63,64 \\
\hline Всього & 45 & 100 & 47 & 100 & \\
\hline
\end{tabular}

За показниками, наведеними в таблиці 3., бачимо, що в контрольній групі високий рівень вразливості мають 11 (24,4\%) опитаних спеціалістів. Середній рівень вразливості мають 16 (35,5\%) опитаних. Низький рівень вразливості мають 18 (40\%) опитаних. В експериментальній групі високий рівень вразливості мають 22 (46,8\%) опитаних спеціалістів, які працюють у сфері інформаційних технологій. Середній рівень вразливості мають 16 (34,04\%) опитаних. Низький рівень вразливості мають 9 (19,15\%) опитаних. Отже, більшість опитаних осіб, які працюють у сфері інформаційних технологій, мають підвищену схильність до вразливості.

Відповідно до опитування за тестом двадцяти тверджень на самоставлення (М. Кун, Т. Мак-Партланд), були отримані такі результати (табл. 4.; ЕГ - експериментальна група (особи, які працюють в IT-сфері), КГ - контрольна група (особи, які працюють в тій же компанії, але їх робота напряму не пов'язана з IT. 
3 таблиці 4. бачимо, що в контрольній групі адекватну самооцінку мають 14 (31,1\%) опитаних. Неадекватно завищена самооцінка в 10 (22,2\%) опитаних, неадекватно занижена - у 16 (35,5\%) опитаних. Нестійкою самооцінка є у 5 (11,1\%) опитаних. В експериментальній групі адекватну самооцінку мають 6 (12,7\%) опитаних. Неадекватно завищена самооцінка у 10 (21,2\%) опитаних, неадекватно занижена - у 14 (29,7\%) опитаних. Нестійкою самооцінка є у $17(36,1 \%)$ опитаних. В контрольній групі найвищий показник має неадекватно занижена самооцінка респондентів, середні показники мають неадекватно завищена й адекватна самооцінка, а найнижчий показник має нестійка самооцінка. В експериментальній групі найвищий показник має нестійка самооцінка респондентів, середні показники мають неадекватно завищена та неадекватно занижена самооцінка, а найнижчий показник має адекватна самооцінка.

Таблиця 4.

\section{Результати дослідження самооцінки працівників IT-сфери за тестом} двадцяти тверджень на самоставлення М. Кун, Т. Мак-Партланд

\begin{tabular}{|c|c|c|c|c|c|}
\hline \multirow{3}{*}{$\begin{array}{c}\text { Характеристики } \\
\text { самооцінки }\end{array}$} & \multicolumn{4}{|c|}{ Кількість досліджуваних } & \multirow{3}{*}{$\begin{array}{c}\text { t-критерій } \\
\text { Стьюдента } \\
\text { (число ступеней } \\
\text { свободи } \mathrm{f}=95, \mathrm{t}- \\
\text { критичне }=1,987 \\
\text { при рівні } \\
\text { значущості } \\
\alpha=0,05 \text { ) }\end{array}$} \\
\hline & \multicolumn{2}{|c|}{ КГ } & \multicolumn{2}{|c|}{$\mathrm{E} \Gamma$} & \\
\hline & абс. число & $\%$ & абс. число & $\%$ & \\
\hline Адекватна & 14 & 31,1 & 6 & 12,7 & 56,57 \\
\hline $\begin{array}{c}\text { Неадекватно } \\
\text { завищена }\end{array}$ & 10 & 22,2 & 10 & 21,2 & 0,00 \\
\hline $\begin{array}{c}\text { Неадекватно } \\
\text { занижена }\end{array}$ & 16 & 35,5 & 14 & 29,7 & 14,14 \\
\hline Нестійка & 5 & 11,1 & 17 & 36,1 & 84,85 \\
\hline Всього & 45 & 100 & 47 & 100 & \\
\hline
\end{tabular}

Відповідно до дослідження за методикою «Колірний тест Люшера», були отримані такі результати (табл. 5.; ЕГ - експериментальна група (особи, 
які працюють в IT-сфері), КГ - контрольна група (особи, які працюють в тій же компанії, але їх робота напряму не пов'язана з IT).

Потребу в задоволенні, спокої, стійкій позитивній прихильності мають 5 (11,1\%) опитаних контрольної групи та 23 (48,9\%) експериментальної; потребу в самоствердженні мають 10 (22,2\%) опитаних осіб контрольної групи та 10 (21,2\%) осіб, які працюють у сфері інформаційних технологій; потреба активно діяти та досягати успіху притаманна 12 (26,6\%) опитаним контрольної групи та 8 (17\%) експериментальної; потребу в перспективі, надіях на краще, мріях мають 18 (40\%) опитаних осіб контрольної групи та 6 (12,7\%) експериментальної.

Таблиця 5.

\section{Результати дослідження вираження психологічних потреб особистості} працівників IT-сфери за колірним тестом Люшера

\begin{tabular}{|c|c|c|c|c|c|}
\hline \multirow{3}{*}{$\begin{array}{c}\text { Психологічні потреби } \\
\text { особистості }\end{array}$} & \multicolumn{4}{|c|}{ Кількість досліджуваних } & \multirow{3}{*}{$\begin{array}{c}\text { t-критерій } \\
\text { Стьюдента } \\
\text { (число ступеней } \\
\text { свободи } \mathrm{f}=95, \mathrm{t}- \\
\text { критичне }=1,987 \\
\text { при рівні } \\
\text { значущості } \alpha=0,05 \text { ) }\end{array}$} \\
\hline & \multicolumn{2}{|c|}{ КГ } & \multicolumn{2}{|c|}{$\mathrm{E} \Gamma$} & \\
\hline & $\begin{array}{l}\text { абс. } \\
\text { Число }\end{array}$ & $\%$ & $\begin{array}{l}\text { абс. } \\
\text { число }\end{array}$ & $\%$ & \\
\hline $\begin{array}{c}\text { Потреба в задоволенні, } \\
\text { спокої, стійкій позитивній } \\
\text { прихильності }\end{array}$ & 5 & 11,1 & 23 & 48,9 & 127,28 \\
\hline $\begin{array}{c}\text { Потреба в } \\
\text { самоствердженні }\end{array}$ & 10 & 22,2 & 10 & 21,2 & 0,00 \\
\hline $\begin{array}{c}\text { Потреба активно діяти i } \\
\text { досягати успіху }\end{array}$ & 12 & 26,6 & 8 & 17 & 28,28 \\
\hline $\begin{array}{l}\text { Потреба в перспективі, } \\
\text { надіях на краще, мріях }\end{array}$ & 18 & 40 & 6 & 12,7 & 84,85 \\
\hline Всього & 45 & 100 & 47 & 100 & \\
\hline
\end{tabular}

Отже, потреба в задоволенні, спокої, стійкій позитивній прихильності має найвищий показник у опитаних i контрольної, i експериментальної групи; потреба в самоствердженні має середній показник вираження в опитаних обох груп; потреба активно діяти та досягати успіху, а також 
потреба в перспективі, надіях на краще, мріях мають найнижчий показник серед опитаних.

Висновки та перспективи подальших досліджень. До чинників, що можуть сприяти виникненню емоційного вигорання у інженерів-програмістів в IT-компаніях відносять суворий контроль над роботою програміста, часті перевірки стану проекту; надмірно стислі терміни виконання проектів і завдань; жорсткий розподіл обов’язків зверху між програмістами в команді; відсутність творчої діяльності в роботі програміста, постійне виконання програмістом рутинних операцій; відсутність можливості ведення нормального діалогу усередині команди, з лідером команди розробників.

Отримані показники за використаними психодіагностичними методиками: Тест-опитувальник В. Лосенкова на визначення імпульсивності та вольової саморегуляції; Методика діагностики рівня «емоційного вигорання» В. Бойка; Шкала вразливості або стресостійкості; Тест двадцяти тверджень на самоставлення (М. Кун, Т. Мак-Партланд); Колірний тест Люшера, уможливили оцінку рівнів імпульсивності та вольової саморегуляції, вразливості та схильності до емоційного вигорання. В основному всі характеристики у досліджених працівників сфери ITтехнологій мають високі показники прояву, а в майже половини досліджуваних респондентів основної досліджуваної групи синдром професійного вигорання виявився сформованим, що робить необхідним розробку програми психокорекції для осіб, які працюють у сфері інформаційних технологій, 3 метою вирішення проблеми їх професійного вигорання. Серед досліджуваних респондентів переважали особи з нестійкою самооцінкою, що можна вважати фактором ризику вірогідності розвитку професійного вигорання.

Отже, слід звернути увагу на вдосконалення психокорекційних втручань, які б не лише підвищувалии, але й стабілізували самооцінку особистості. 


\section{Список використаних джерел}

1. Бойко В. Енергія емоцій у спілкуванні: погляд на себе та на інших / В. Бойко - М.: Филинъ, 1999. - 472 с.

2. Большакова Т. Особистісні детермінанти та організаційні фактори психічного вигорання в медичних працівників: автореф. дис. / Т. Большакова. - Ярославль, 2004. - 27 с.

3. Варнава У. Експериментальне дослідження незрілих пихологічних захистів особистості / У. Варнава // Наук. записки Інституту психології імені Г. С. Костюка АПН України : зб. наук, праць. - 2006. - Вип. 29. - С. 102-106.

4. Водоп'янова Н. Синдром «психічного вигорання» в коммунікативних професіях / Н. Водоп'янова [ред. Г. Нікіфоров] // Психологія здоров’я. - СПб. : СПбГУ, 2000. - С. 443-463.

5. Єршов А. Про людський та естетичний фактори в програмуванні / А. Єршов //Вибрані праці. - Новосибірськ : Наука, 1994. - 316 с.

6. Лаврова М. Теоретичний аналіз сучасних поглядів на поняття «емоційне вигорання» / М. Лаврова // Вісник Одеського національного університету. Психологія. - 2014. - Т. 19. - Вип. 2. - С. 194-202.

7. Мінін Д. Емоційно-особистісні пре диктори психічного вигорання адвокатів у різних видах судочинства:автореф.дис./Д.Мінін.-СПб.,2016.-23 с.

8. Назарук Н. «Згорання» та професійна деформація особистості: порівняльний аналіз / Н. Назарук // Зб. наукових праць: філософія, соціологія, психологія. - Івано-Франківськ: Плай, 2004. - Вип. 9 . - Ч. І. - С. 186-194.

9. Назарук Н. Каузально-телеологічний формат профілактики «професійного вигорання» вчителя / Н. Назарук // Психологія особистості. 2012.- № 1 (3).- C. 119-128.

10. Неруш Т. Основні етапи вивчення феномену вигорання / Т. Неруш [Електронний ресурс].- режим доступу:https://phpp.sgu.ru/ru/articles/ osnovnye -etapy-izucheniya-fenomena-vygoraniya. 
11. Ожогова Є. Взаємозв’язок синдрому “психічного вигорання» та особливостей ціннісно-смислової сфери в педагогів / Є. Ожогова // Психологічний журнал.- 2008.- Т. 5, № 3.- С. 17-28.

12. Орел В. Синдром вигорання: діагностика, корекція / В. Орел // Психологічний журнал.- 2001.- Т. 22, № 1.- С. 76-92.

13. Орел В. Структурно-функціональна організація та генезис психічного вигорання : автореф. дис. / В. Орел.- Ярославль, 2006.- 19 с.

14. Полякова О. Категорія та структура професійних деформацій /O. Полякова //Національний психологічний журнал.-2014.-№ 1.- С. 57-64.

15. Ракицька А. Синдром емоційного вигорання як предмет соціальнопсихологічних досліджень [Електронный ресурс] / А. Ракицька.- Режим доступу : http://elib.bsu.by/handle/123456789/97946

16. Сучасні проблеми дослідження синдрому вигорання у фахівців комунікативних професій: колективна монографія [ред. В. Лук'янов, Н. Водоп’янова, В. Орел, С. Подсадний, Л. Юр’єва, С. Ігумнов].- Курск : Курськ.держ. ун-т, 2008. - 336 с.

17. Сочнєв В. Теоретичні основи вивчення феномену професійної деформації / В. Сочнєв [Електронный ресурс].- режим доступу: https://cyberleninka.ru/article/n/teoreticheskie-osnovy-izucheniya-fenomenaprofessionalnoy-deformatsii

18. Старовойт О. Невпевненість і емоційне вигорання особистості як бар'єри інноваційної діяльності / О. Старовойт //Вісник Інституту розвитку дитини. Серія: Філософія, педагогіка, психологія.-2014.-Вип.36.- С. 50-57.

19. Стебловська А. Теоретичне уявлення поняття «синдром емоційного вигорання» в психолого-педагогічній літературі / А. Стебловська [Электронный pесурс]. - режим доступу: https://cyberleninka.ru/article/n/ teoreticheskoe-predstavlenie-ponyatiya-sindrom-emotsionalnogo-vygoraniya-vpsihologo-pedagogicheskoy-literature 
20. Форманюк T. Синдром «емоційного згорання» як показник професійної дезадаптації вчителя / Т. Форманюк // Питання психології. 1994. - № 6. - C. 5-64.

21. Шнайдер О. Психологічні особливості емоційного вигорання працівників сфери інформаційних технологій / О. Шнайдер // Наукові записки Національного університету «Острозька академія». Серія «Психологія і педагогіка». - 2016. - Вип. 26. - С. 144-148.

22. Шнейдерман Б. Психологія програмування: Людські фактори в обчислювальних та інформаційних системах / Б. Шнейдерман. - М.: Радіо та зв’язок, 1984. - 304 с.

23. Юдчиць Ю. До проблеми професійної деформації / Ю. Юдчиць // Журнал прикладної психології. - 2008. - № 2. - С. 17-22.

\section{References}

1. Bojko, V. (1999), Enerhyia emotsyj v obschenyy: vzghliad na sebia y na druhykh [The energy of emotions in communication: a look at themselves and others], Fylyn', Moscow, Ru.

2. Bol'shakova, T. Lychnostnye determynanty y orhanyzatsyonnye faktory psykhycheskoho vyhoranyia u medytsynskykh rabotnykov: avtoref. dys. [Personal determinants and organizational factors of mental burnout in health care workers: Author. dis.], Yaroslavl', Ru.

3. Varnava, U. (2006), "Experimental study of immature psychological defenses of the individual", Naukovi zapysky Instytutu psykholohii imeni H. S. Kostiuka APN Ukrainy: Zb. nauk, prats', vol. 29, pp. 102-106.

4. Vodop'ianova, N. (2000), "The syndrome of "mental burnout" in communicative occupations", Psykholohyia zdorov'ia, pp. 443-463, Ru.

5. Ershov, A. (1994), O chelovecheskom y estetycheskom faktorakh v prohrammyrovanyy [On the human and aesthetic factors in programming], Nauka, Novosybyrsk, Ru. 
6. Lavrova, M. (2014), "Theoretical Analysis of Statements for Understanding "Emotion of Viranation", Visnyk Odes'koho natsional'noho universytetu. Psykholohiia, vol. 2, pp.194-202.

7. Mynyn, D. (2016), Emotsyonal'no-lychnostnye predyktory psykhycheskoho vyhoranyia advokatov $v$ razlychnykh vydakh sudoproyzvodstva : avtoref. dys. [Emotional-personal predictors of mental burnout of lawyers in various types of legal proceedings: Author. dis., SPb., Ru.

8. Nazaruk, N. (2004), "The causal-teleological format of the professional reading of the "vocational vigilance" by the reader", Zb. naukovykh prats': filosofiia, sotsiolohiia, psykholohiia. - vol. 9., Ch. I. . pp. 186-194.

9. Nazaruk, N. (2012), "The causal-teleological format of the professional reading of the "vocational vigilance", Psykholohiia osobystosti, vol. 1 (3), pp. 119 128.

10. Nerush, T., "The main stages of the study of the phenomenon of burnout", [Online], available at: https://phpp.sgu.ru/ru/articles/osnovnye-etapyizucheniya-fenomena-vygoraniya

11. Ozhohova, E. (2008), "Interrelation of the syndrome of "mental burnout and peculiarities of value-semantic sphere among teachers", Psykholohycheskyj zhurnal, vol. 5 (3). pp. 17-28.

12. Orel , V. /(2001), "Burnout syndrome: diagnosis, correction", Psychological journal, vol. 22 (1), pp. 76-92

14. Orel, V. (2006), Strukturno-funktsyonal'naia orhanyzatsyia y henezys psykhycheskoho vyhoranyia: avtoref. dys. [Structural and functional organization and the genesis of mental burnout: author. dis.], Yaroslavl', Ru.

15. Poliakova, O. (2014), "Category and structure of professional deformations", Natsyonal'nyj psykholohycheskyj zhurnal, vol 1, pp. 57-64.

16. Rakytskaia, A. Syndrome of emotional burnout as a subject of social and psychological research [Online], available at: http://elib.bsu.by/ handle/123456789/97946 
17. Luk'ianov, V. Vodop'ianova, N. Orel, V. Podsadny, S. and ets. (2008), Sovremennye problemy yssledovanyia syndroma vyhoranyia u spetsyalystov kommunykatyvnykh professyj: kollektyvnaia monohrafyia [Current problems of burnout syndrome research in communicative professions: a collective monograph, Kursk. Ru.

18. Sochnev, V. Theoretical Foundations of Studying the Phenomenon of Professional Deformation [Online], available at: https://cyberleninka.ru/article/n/ teoreticheskie-osnovy-izucheniya-fenomena-professionalnoy-deformatsii

19. Starovojt, O. (2014), "Uncertainty and emotional burnout of the individual as barriers to innovation", Visnyk Instytutu rozvytku dytyny. Ser.: Filosofiia, pedahohika, psykholohiia, vol. 36, pp. 50-57.

20. Steblovskaia, A. Theoretical representation of the concept of "emotional burnout syndrome" in the psychological-pedagogical literature [Online], available at: https://cyberleninka.ru/article/n/teoreticheskoe-predstavlenie-ponyatiyasindrom-emotsionalnogo-vygoraniya-v-psihologo-pedagogicheskoy-literature

21. Formaniuk, T. (1994), "Syndrome of "Emotional Combustion" as an Indicator of Professional Teacher Disadaptation", Voprosy psykholohyy, vol. 6, pp. $5-64$.

22. Shnajder O. Psykholohichni osoblyvosti emotsijnoho vyhorannia pratsivnykiv sfery informatsijnykh tekhnolohij / O. Shnajder // Naukovi zapysky Natsional'noho universytetu «Ostroz'ka akademiia». Ser. Psykholohiia i pedahohika. - 2016. - Vyp. 26. - S. 144-148.

23. Shnejderman B. Psykholohyia prohrammyrovanyia: Chelovecheskye faktory $v$ vychyslytel'nykh y ynformatsyonnykh systemakh [Psychology of programming: Human factors in computing and information systems], Moscow, $\mathrm{Ru}$.

24. Yudchyts ,Yu. (2008), "To the problem of professional deformation”, Zhurnal prykladnoj psykholohyy, vol. 2, pp. 17-22. 